\title{
Prey selection of lions Panthera leo in a small, enclosed reserve
}

\section{R.J. POWER}

Power, R.J. 2002. Prey selection of lions Panthera leo in a small, enclosed reserve. Koedoe 45(2): 67-75. Pretoria. ISSN 0075-6458.

Annual trends in numbers of ungulate species on a $15 \mathrm{~km}^{2}$ reserve from 1993 to 1998, were evaluated in the context of lion Panthera leo reintroduction during 1996, and subsequent predation by them. The ungulate prey base was enumerated annually by aerial counts and a road count that took place during 1998. The lion prey record was obtained from direct observations of a radio-located pride of eight lions and daily reserve management records. All ungulate species that underwent precipituous declines were also the most important prey to lions, comprising over $80 \%$ of their prey, and they were preyed upon according to their availability. Lion predation was causal for the declines in wildebeest Connochaetes taurinus, blesbok Damaliscus pygargus phillipsi and warthog Phacochoerus africana, while the decline in kudu Tragelaphus strepsiceros was only partly ascribed to lions, as other non-lion related mortality sources were identified. The only ungulate species to increase subsequent to lion reintroduction was the impala Aepyceros melampus, which was furthermore under-selected by lions. The uncontrolled population growth of impala could have elicited ecological degradation, and it was advised to either not stock impala, or otherwise control their numbers if lions are unable to do so. Lion hunting success and kill rate, were $21 \%(n=63)$ and 1 kill/4.4 days, respectively. Three bushpigs Potamochoerus larvatus were killed but not utilised, and this finding is corroborated by an intensive study in Kwazulu-Natal, and this aversion is discussed. Predators can cause unprecedented declines of their prey where the prey are confined to small reserves that have no refuge from predation. On an annual basis, prey may need to be augmented to sustain predators on small reserves.

Key words: predation, predator-prey relationships, small population management, small reserves, wildlife management.

\section{R.J. Power, Centre for Wildlife Management, University of Pretoria, Pretoria, 0002} Republic of South Africa.

\section{Introduction}

Predators are unable to regulate their prey where their prey populations undergo seasonal migrations of varying degrees (Sinclair et al. 1985; Mills \& Retief 1984; Mills \& Shenk 1992). However, where prey populations are resident, the predator can regulate and even limit its prey populations (Hirst 1969; Smuts 1978; Fryxell et al. 1988; Caughley \& Sinclair 1994; Sinclair 1995; Harrington et al. 1999; Peel \& Montagu 1999). Where the prey are at very low densities, the predator can even eliminate the prey (Fryxell et al. 1988). Analogous to this, enclosed reserves become islands in which the prey are compelled to be resident, and depending on the number of predators, the prey can be regulated in the same way.

On a managed reserve of this nature, with lions Panthera leo, the impact that predation can have on the prey base is an important consideration (Mills 1991; Van Schalkwyk 1994; Viljoen 1996; Van Dyk 1997; Hunter 1998). To address this, one requires annual prey numbers at least, and a record of what the lions prey upon (Mills 1991; Van Schalkwyk 1994; Hunter 1998). However, to accurately and unequivocally demonstrate that a predator has had an impact on the prey; one requires additional information on the 
demography of the prey populations; other non-predation related mortality sources in the dynamics of the prey populations; and how the predator selects for species, gender, age or condition (Mills 1991; Hunter 1998). This paper aimed to investigate lion prey selection in Southern Africa's smallest reserve containing free-ranging lions. This reserve was the Madjuma Lion Reserve (MLR), that was a part of the greater Mabula Game Reserve. The surface area size was $15 \mathrm{~km}^{2}$, which was even smaller than the smallest extensively managed reserves $\left(<1000 \mathrm{~km}^{2}\right)$ that were under review by Van Schalkwyk (1994).

On fairly small reserves $\left(40-140 \mathrm{~km}^{2}\right)$, predators like lion and cheetah Acinonyx jubatus, have caused drastic declines in their preferred prey (Hunter 1998; Peel \& Montagu 1999). Hunter (1998) pointed out that it remains to be seen whether predators can cause extinctions in their prey in a small reserve. Contrary to the difficulties of studying a typical African multi-predator system (Smuts 1978; Mills 1991; Bothma 1997), this reserve with one notable predator, was expected to yield a less complex understanding of a predator-prey relationship. Various aspects of predation such as hunting success, kill rates and prey species selection were examined in the light of prey abundance, and inference was to be made on the impact of this predation on prey populations.

In 1998, the MLR pride consisted of eight lions, which were borne from a reintroduced stock of three lionesses and an adult male that came from the Pilanesberg National Park (PNP). The lionesses were born in PNP, of which these lions originally hailed from Etosha National Park (ENP), and the extent to which they behave like them (Stander 1992a; 1992b; Stander \& Albon 1993) would be investigated in conjunction with the main objectives. One of the females already had a litter of four cubs born at the beginning of June 1997. The sex ratio was 3:1, males to females. In May 1998, the roster was brought to 10 when two cubs were born.

\section{Study area}

Madjuma Lion Reserve is situated in the Limpopo Province, South Africa, between latitudes $24^{\circ} 40^{\prime}-24^{\circ} 44^{\prime} \mathrm{S}$, and longitudes $27^{\circ} 57^{\prime}-27^{\circ} 59^{\prime} \mathrm{E}$. The underlying geology is comprised mainly of granitic rock types, as well as sandstone and metamorphic rock, that are, in turn, overlain by six soil types (Bredenkamp \& Van Rooyen 1990). The annual rainfall varies between $300 \mathrm{~mm}$ and $900 \mathrm{~mm}$, with a mean of $602 \mathrm{~mm}$ per annum (South African Weather Bureau: Rooiberg station). The vegetation type of the region is Mixed Bushveld (Van Rooyen \& Bredenkamp 1996), which is dominated by Combretum apiculatum-woodland and smaller patches of old lands grassland undergoing succession with Cynodon dactylon and Cenchrus ciliaris (Bredenkamp \& Van Rooyen 1990). The only other large carnivore present is the brown hyaena Hyaena brunnea (Power 1998), which is not known to be an active predator, as it is mostly a scavenger (Mills 1990). The reserve contains 10 ungulate species, of which nine can be regarded as prey, and serve that purpose to varying degrees. The only function of the MLR is tourism, where rangers escort guest clientele from the Mabula Game Lodge to see the lions.

\section{Methods}

The study period during 1998 was 95 days in total (Power 1998), and that from which data was available from in 1997 was 285 days (after Jakoby 1997). During 1998, the study period spanned intermittent intervals of two weeks between March and October. During 1997, data was made available outside the researcher's study period too, hence the longer effective study period. Radio-located lions within the pride were followed in a landrover and directly observed in the same way as other workers had done (Schaller 1972; Bryden 1978; Elliot \& Cowan 1978; McBride 1984; Van Orsdol 1982; 1984; Packer et al. 1990; Scheel \& Packer 1991; Stander 1992a; b; Stander \& Albon 1993; Mills \& Shenk 1992; Scheel 1993; Viljoen 1993; Mills 1996; Hunter 1998; Funston et al. 2001). Four lions were fitted with 148 $\mathrm{mHz}$ radio-collars, with a 0.25 wave antennae (MK6, Telonics, Arizona). The radio signals were received by a portable receiver (Telonics, Arizona) 
connected to a hand-held two-element Yagi antennae. The radio-collared individuals were members of the four different subgroups of the pride that frequently split apart from one another (Power 1998). Observations were undertaken daily in a non-random fashion, which is perceived as biased (Mills 1996), but regarded as unimportant, as the lions and their kills could be readily located and it was assumed that all prey killed during the study period could be tallied. Nocturnal observations ranged between short-duration observations up to six hours, and long-duration observations which were at least 12 hours, and were dependent on the likelihood that lions would kill (cf. Mills 1996). The adult females were the focal animals as they were regarded as the hunting lions (Van Orsdol 1982; Mills \& Shenk 1992), and all their activities were observed. A Coleman spotlight (300 $000 \mathrm{CP}$ ) was used, with an attached red-filter (Stander 1992a; Viljoen 1993) to observe the lions at night, but was switched off when the lions hunted (Mills \& Shenk 1992). Observations were made with a pair of Leica $10 \times 42$ BA binoculars, at distances up to $400 \mathrm{~m}$.

All kills were recorded, including the species, sex and age where possible. It was not always possible to gather the last two characteristics under direct observations, and where that was the case, this information was obtained from returning to the carcass the following day. Known ageing and sexing criteria were used (McBride 1984; Viljoen 1993; Bothma 1996) to assign three age-classes: adults, subadults and juveniles. The reserve management provided information on kills made from their daily monitoring. In some cases the age and sex were not recorded and hence they were assigned as unknown. Data collected from the reserve management in the previous year and that collected by researchers in 1997 (Jakoby 1997) and 1998 (Power 1998) was used, and re-analysed for this paper.

Lion hunting success was determined as the number of kills made per species, out of all hunting attempts for all prey species grouped (Van Orsdol 1984; Stander \& Albon 1993; Funston et al. 2001). A hunt was defined according to Schaller (1972), and the outcome of a hunt ended in prey being killed or otherwise fleeing upon detecting hunting lions.

When examining prey species selection, overt selection was inferred when killed proportions of a certain species exceeded the proportions with which they occurred in, in the study area (Karanth \& Sunquist 1995). The road-count numbers of the five most common ungulates, and the prey numbers killed by lions during 1998 (Power 1998) were used to calculate the expected and observed number of prey killed respectively. The log-likelihood ratio or $G$-test statistic (Zar 1986) was used to detect prey species selection. Where a difference was found, Bonferroni simultaneous confidence intervals were proceeded to, as in other use-availability data (Neu et al. 1974; Byers et al. 1986).

The kill rate by hunting lionesses (Van Orsdol 1982; Mills \& Shenk 1992) over the specified study period was determined as the total number of kills/study period (days). This was done for each species and extrapolated over a one year period.

\section{Results}

Based on the aerial census figures, the trend was for most ungulate prey populations to grow prior to lion reintroduction, and then decline subsequent to lion reintroduction. The impala Aepyceros melampus numbers however increased, while the warthog Phacochoerus africana numbers remained relatively stable with minor fluctuations (Fig. 1).

Over the period (1997-1998), 86 lion kills were recorded (Table 1), $87 \%$ were com-

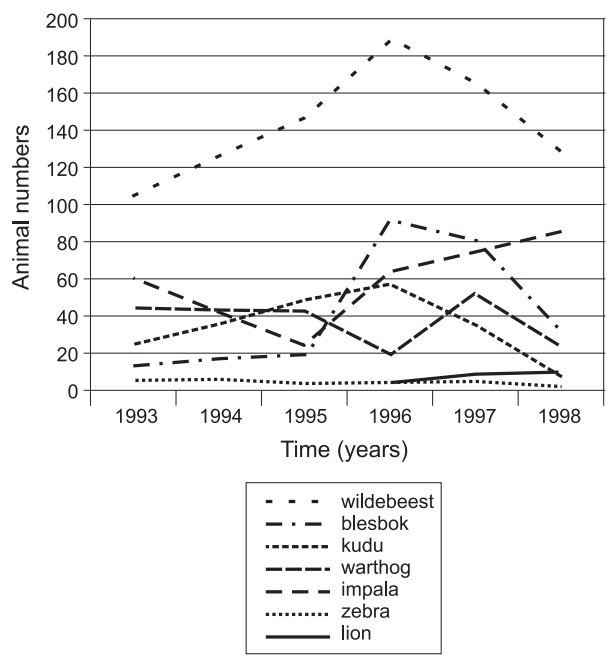

Fig. 1. Line graphs showing long-term trends in the ungulate and lion numbers of MLR since 1993. Lion reintroduction took place in 1996. The blesbok Damaliscus pygargus phillipsi numbers were supplemented during 1996. 
Summary of all lion kills $(n=86)$ made from March 1997 to October 1998 which include gender and relative age characteristics of prey

\begin{tabular}{|c|c|c|c|c|c|c|c|c|c|c|}
\hline \multirow[t]{3}{*}{ Prey species } & \multicolumn{9}{|c|}{ Gender } & \multirow[t]{3}{*}{ Totals } \\
\hline & \multicolumn{3}{|c|}{ Males } & \multicolumn{3}{|c|}{ Females } & \multicolumn{3}{|c|}{ Unknown } & \\
\hline & Adult & Subadult & Juvenile & Ad. & Subad. & Juv. & Ad. & Subad. & Juv. & \\
\hline Wildebeest & 13 & 2 & & 12 & & & & & 4 & 31 \\
\hline Blesbok & 5 & & & 6 & & & 2 & & 1 & 14 \\
\hline Kudu & 8 & 3 & & & & & & & & 11 \\
\hline Warthog & 4 & & & 9 & & & 1 & & 4 & 18 \\
\hline Impala & 1 & & & 1 & 1 & & & & & 3 \\
\hline Bushpig & & & & & & & 3 & & & 3 \\
\hline Genet & & & & & & & 1 & & & 1 \\
\hline Porcupine & & & & & & & 1 & & & 1 \\
\hline Aardvark & & & & & & & 1 & 1 & & 2 \\
\hline Ostrich & & & & 2 & & & & & & 2 \\
\hline
\end{tabular}

Table 2

Summary of total mortality percentages of five ungulates on MLR, inclusive of all lion kills and other mortality sources and the annual kill rate

\begin{tabular}{ccccc}
\hline Prey species & \% lion kills in & \% lion kills in & Other non-lion related & Per annum \\
& $1998(n=30)$ & $1997(n=55)$ & mortality (1997), & as \% of total mortality
\end{tabular}

\begin{tabular}{lrrrr}
\hline Wildebeest & 40.0 & 36.4 & $16.7(n=24)$ & 30.7 \\
Blesbok & 10.0 & 18.2 & $9.1(n=11)$ & 13.5 \\
Kudu & 16.7 & 10.9 & $72.7(n=22)$ & 10.6 \\
Warthog & 20.0 & 20.0 & $0(n=11)$ & 13.6 \\
Impala & 0.0 & 5.4 & $0(n=3)$ & 2.8
\end{tabular}

prised of four ungulate species, and $93 \%$ were prey between 50 and $300 \mathrm{~kg}$. Wildebeest Connochaetes taurinus comprised $37 \%$, warthog $21 \%$, kudu Tragelaphus strepsiceros $13 \%$, and blesbok $16 \%$. A small spotted genet Genetta genetta and three bushpigs Potamochoerus larvatus were not utilised. The one bushpig was though partially eaten, but the lions regurgitated the meat subsequently. Anomalous prey like porcupine Hystryx africaeaustralis, aardvark Orycteropus afer and ostrich Struthio camelus were also recorded.

Male individuals comprised $55 \%(n=66)$ of kills where gender was known, while adults comprised $81 \%$ of all prey, while younger individuals (subadults \& juveniles) made up the remainder (Table 1).

There were a total of 63 hunts observed, of which 13 were successful. Therefore hunting success was $21 \%$ for all prey species. The kill rate was one kill every 4.4 days, implying that 83 kills were made annually, regardless of whether they were utilised or not. The annual off-take by lions for the prey animals was calculated (Table 2). Other non-lion related mortality (Table 2) sources included fence electrification, old age, and various unidentified sources, which could have included food shortages. Excluding the small recruitment of the year for each species (Madjuma census figures 1997), the calculat- 
Table 3

Prey species selection by lions in the MLR based on the 1998 road count and kill record, using Bonferroni simultaneous confidence intervals. $P_{o}=$ observed use proportion, $P_{i o}=$ expected use proportion,

$\mathrm{n}=$ kill sample, total $Z=2.34$, Selection status: $-v e=$ avoidance, $+v e=$ overt selection,

$0=$ selection in accordance with numbers

\begin{tabular}{lccccc}
\hline $\begin{array}{l}\text { Prey species } \\
\text { (1998 road counts) }\end{array}$ & $\mathrm{P}_{\mathrm{o}}$ & $\mathrm{P}_{\text {io }}$ & $n$ & Bonferroni intervals & $\begin{array}{c}\text { Selection } \\
\text { status }\end{array}$ \\
\hline Wildebeest & 0.460 & 0.44 & 12 & $-0.06<\mathrm{P}_{\text {io }}<0.98$ & 0 \\
Blesbok & 0.115 & 0.104 & 3 & $-0.22<\mathrm{P}_{\text {io }}<0.45$ & 0 \\
Kudu & 0.192 & 0.061 & 5 & $-0.02<\mathrm{P}_{\text {io }}<0.37$ & 0 \\
Warthog & 0.231 & 0.100 & 6 & $-0.21<\mathrm{P}_{\text {io }}<0.67$ & 0 \\
Impala & 0.000 & 0.288 & 0 & $-0.2<\mathrm{P}_{\text {io }}<0.20$ & -ve \\
\hline
\end{tabular}

ed per annum kill rate does conform to the same number at which ungulate populations declined by (Table 2) suggesting that predation over-rode the net growth rate

There was an overall significant degree of prey species selection by the MLR lions from the road count data $(G=47, d f=4$, $p<0.001)$. Owing to this, it was decided to proceed to construct Bonferroni confidence intervals and further analyse this claim. It was found that the MLR lions appeared to prey on four ungulate prey species according to their numbers in the populations, and impala were significantly under-utilised (Table 3).

\section{Discussion}

As predicted by predation theory (Caughley \& Sinclair 1994), small resident prey populations, when subject to predation, without refuge from predators, or where migration is inhibited (fencing), can undergo significant declines (Fryxell et al. 1988; Mills 1991; Sinclair 1995; Hunter 1998; Peel \& Montagu 1999). At MLR, the four ungulate species that underwent dramatic declines, were also the most important prey to lions, comprising over $80 \%$ of lion kills. It was imminent that some ungulate populations could have become extinct within a year (Fig. 1), which remains to be seen on a small reserve, as Hunter (1998) pointed out. In identifying the cause of prey declines, it is imperative to also account for other sources of mortality, other than predation (Mills 1991; Hunter 1998), and accordingly, all non-lion related mortality was recorded for the MLR (Table 2). For wildebeest and blesbok, nonlion related mortality accounted for a small fraction $(<17 \%)$ of total mortality, and in warthogs no other source of mortality could be identified other than lion predation (Table 2). However, in the case of kudu, nonlion related mortality was much greater $(>70 \%)$ than that contributed by predation per se. It is thus argued that lion predation was the main cause of population declines in wildebeest, blesbok and warthog, while predation might have had a secondary role in hastening the decline in the kudu population. In kudu, mortality is often associated with dry season food shortages (Owen-Smith 1984) and the consequences of dimorphism in the long-term, particularly in adult males, which may be further exacerbated by predation (Owen-Smith 1993).

Lion predation was aimed at the adult segment of ungulate populations, moreover juvenile predation, which is most certainly because the 1998 study period (Power 1998), fell outside the main ungulate seasonal birth peak. Alternatively, the study methodology could have been the reason. Prey like warthogs and juvenile ungulates are rapidly consumed (8 $\mathrm{min}$ for juvenile warthog: Power 1998) and a study of this nature might have overlooked the fraction of smaller prey (Mills 1996). Elsewhere, higher juvenile predation by lions was reported, which was pre- 
sumably because of the continuous presence of observers with study lions (McBride 1984; Viljoen 1993; Stander 1992a). Notwithstanding, if adult mortality was important at MLR, it could have been a contributor to the observed population declines, as lion predation was simulated to have the greatest impact in the KNP when the adult segment of the zebra (Mills \& Shenk 1992) and roan (Harrington et al. 1999) populations were preyed upon.

The MLR lions favoured wildebeest, warthog and kudu as prey, like they do in savannas elsewhere (Mills 1991), that was in accordance with their numbers (Table 3 ). This would however be the first published record of blesbok as lion prey, as lions have been eliminated from the blesbok's distribution range, though this species is non-native to the Limpopo Province bushveld (Skinner $\&$ Smithers 1990). The absence of zebra predation was a reflection of their numbers, and it is suggested that they should be stocked on account of them being an important prey species (Pienaar 1969; Whateley \& Brooks 1985; Mills 1991; Mills \& Shenk 1992; Mills \& Shenk 1992; Scheel 1993; Stander \& Albon 1993; Viljoen 1993; Funston et al. 2001). The fact that bushpig were not utilised, and when so, regurgitation took place can be corroborated with the findings of Hunter (1998) at Phinda. He reported 10 out of 13 bushpig kills that were abandoned and only partially fed upon (Hunter 1998). Boma-contained lions have also been known to show disdain to eating bushpig meat (Van Dyk pers. comm.). Two reasons are put forward why this could be so. Firstly, bushpig might have glandular secretions that may impart some distastefulness to the flesh, which would be to the disdain of the eater and explain why lions regurgitate this once eating. Secondly, lions could be construed as 'finicky' carnivores that feed only on true herbivores on the appropriate secondary trophic level. The bushpig is more omnivorous than the warthog (Skinner \& Smithers 1990), and it could be likened to another carnivore, which is infrequently preyed upon (cf. leopards). However, nutritionallystressed lions, or any other predator for that matter, would not have an aversion to feeding on non-herbivore prey (Griffiths 1975; Eloff 1984; Mills 1984; Skinner \& Smithers 1990). This phenomenon has largely been overlooked as bushpig are either rare or absent from many of the sites where lions have been intensively studied. Only a fullyfledged research study on the myochemistry of bushpig meat could properly elucidate this answer.

The MLR hunting success is intermediary between that reported for ENP (15\%: Stander \& Albon 1993) and other areas such as the R'wenzori National Park (28.9 \%: Van Orsdol 1984). Hunting success was highest on dark moonless nights (Power 1998), which is due to the lessened ability of prey in detecting hunting lions (Van Orsdol 1984; Stander \& Albon 1993; Funston et al. 2001). Contrary to ENP lions (Stander \& Albon 1993), MLR lions had exercised some diurnal hunting with fairly high success (Power 1998), which is perhaps because of the closed nature of vegetation (Funston et al. 2001), and the availability of diurnal warthog, which are a main contributor to diurnal hunting success in lions (Van Orsdol 1984). The extent to which the MLR lions hunted with a coordinated strategy of ENP lions (Stander 1992b), could not be properly ascertained owing to the conditions of the vegetation and darkness. For those that were witnessed $(n=6)$ during daylight, the largest lioness consistently occupied a central position in all hunting, whilst the two smaller lionesses were wings that encircled the prey as described by Stander (1992b).

A kill rate of seven wildebeest per killing lioness per annum for KNP (Mills \& Shenk 1992; Funston 1999) is lower than the 10.2 wildebeest per lioness per year for MLR, which is perhaps because of the limitations in prey switching on MLR when compared to the more diverse KNP prey base. MLR lions exhibited no significant selection for any species, except for impala. Non-selective predation patterns occur where large prey are scarce (Karanth \& Sunquist 1995), and where prey choice is seemingly limiting (Griffiths 1975). At Phinda, wildebeest were 
preyed upon at three times their availability, warthogs twice, and kudu at their availability, while impala were under-selected (Hunter 1998) like the MLR. It appears that impala are more frequently preyed upon in larger reserves (Bryden 1978; Whateley \& Brooks 1985; Mills \& Biggs 1993; Funston et al. 2001), and the fact that they were significantly under-represented in the diet of MLR lions, might be ascribed to the extreme alertness and superior vigilance behaviour of this species (see Mooring 1999). At Phinda, impala underwent a $200 \%$ increase in vigilance (measured as the proportion of individuals being vigilant) following felid reintroduction (Hunter \& Skinner 1997), which suggests that the slightly higher predation upon them during 1997 (Jakoby 1997), was because impala were more naïve to the presence of lion. With a constrained and below average pride range size (ca. $15 \mathrm{~km}^{2}$ ), it is contended that the encounter rate with impala would be much higher than it would be in a larger reserve. In larger reserves, then, larger lion prides frequently range out of the ranges of impala, and the impala thus have a reprieve in awareness for lions. With the higher predator-prey encounter rates experienced on smaller reserves, it could be the primer to 'fine-tune' their senses to a familiar predator. It is hypothesised then that impala will feature less in the diet of lions when their pride ranges are small, whether this is because of confinement or ecological reasons. Since impala were infrequently preyed upon they would not be serving their purpose as prey. Despite this, what is more at stake, though, is that an ever increasing abundance of impala could severely impact upon the vegetation and other herbivore habitats. Impala are highly- selective mixed feeders (Fairall \& Klein 1984; Du Toit 1988; Skinner \& Smithers 1990), that have the ability to denude the amount and change the composition of the herbaceous layer to the detriment of other herbivores (Wentzel et al. 1991), and reduce predator stalk cover (Power 1998), which is an important variable influencing hunting success (Kruuk 1986; Sunquist \& Sunquist 1989; Van Orsdol 1984; Funston et al. 2001). Following this, for ecological reasons, managers should closely monitor impala numbers, and intervene to control impala numbers if lions are unable to do so. Impala appear to successfully utilise a habitat that can be construed as 'enemy-free space' (Jeffries \& Lawton 1984; Begon et al. 1996), which would not be favoured by potentially competing herbivores (Wentzel et al. 1991), or otherwise not conducive to the hunting antics of lions, owing to the reduction in stalk cover (Van Orsdol 1984), which is typical of impala habitat (Wentzel et al. 1991).

Prey like wildebeest, kudu, warthog, zebra and blesbok would serve effective buffer prey species, if there is a desire to safeguard rare or expensive ungulate populations. Wildebeest are especially a favoured prey species, and lions are known to have a great impact on their populations in both large and small reserves (Mills \& Shenk 1992; Mills \& Biggs 1993; Hunter 1998; Peel \& Montagu 1999). On small reserves ( $<2000$ ha) managers might be compelled to restock reserves with prey or otherwise increase area size through the conservancy approach, and if that is not an option, to not liberally stock small reserves with lions. Large protected areas that create prey confinement by water provisioning can be prone to prey declines by predators (Kruuk 1986; Young 1992; Hunter 1998; Harrington et al. 1999), in the same way that small enclosed reserves would. In managing an assemblage of predators on a reserve, it can be expected that similar prey declines of the same species will occur, and the real challenge is to accommodate this. Research would need to be aimed at sustainability of reserves for predators, but in the meantime the suggested practice is to have to re-supplement prey populations on small reserves.

\section{Acknowledgements}

I would like to thank the management of the Mabula Game Reserve, in particular Mr. Danie De Bruyn, Riaan Van Zyl and Chris Van der Valk; all rangers from the Mabula Game Lodge for information dissemination; Mr. Ben Orban of the University of Pre- 
toria; various members of the African Lion Working Group (ALWG) for allowing me to present this information at their last meeting, and for encouragement to present it in this paper.

\section{References}

Begon, M., J.L. Harper \& C.R. Townsend. 1996. Ecology. Oxford: Blackwell Science.

BотнмA, J. DU P. 1996. Game ranch management. Pretoria: Van Schaik.

Bothma, J. Du P. 1997. Larger carnivores on game ranches. Pp. 58 - 81. In: VAN HEERDEN, J (ed.). Proceedings of a symposium on lions and leopards as game ranch animals. Pretoria: Wildlife group of the South African Veterinary Association, Onderstepoort.

BRedenKamp, G. J. \& N. van Rooyen. 1990. The vegetation and wildlife management of the Mabula Game Reserve. Pretoria: Ekotrust.

BRYDEN, B.R. 1978. The biology of the African lion (Panthera leo Linnaeus, 1758) in the Kruger National Park. MSc thesis, University of Pretoria, Pretoria.

Byers, C.R., R.K. Steinhorst \& P.R. Krausman. 1984. Clarification of a technique for analysis of utilisation-availability data. Journal of Wildlife Management 48: 1050-1053.

Caughley, G. \& A.R.E. Sinclair. 1994. Wildlife ecology and management. Cambridge: Blackwell Science.

Du ToIT, J.T. 1988. Patterns of resource use within the browsing ruminant guild in the central Kruger National Park. PhD dissertation, University of Witwatersrand, Johannesburg.

ElLIOT, J.P. \& I.M. Cowan. 1978. Territoriality, density and prey of lions in Ngorongoro Crater, Tanzania. Canadian Journal of Zoology 56: 1726-1734.

Eloff, F.C. 1984. Food ecology of the Kalahari lion Panthera leo vernayi. Koedoe (Supplement) 27: 249-258.

FAIRALL, N. \& D.R. KLEIN. 1984. Protein intake and water turnover: a comparison of two equivalently sized African antelope, the blesbok (Damaliscus dorcas) and the impala (Aepyceros melampus). Canadian Journal of Animal Science 64: 212-214.

FrYXell, J.M., J. Greever \& A.R.E. Sinclair. 1988. Why are migratory ungulates so abundant? American Naturalist 131: 781-798.

Funston, P.J., M.G.L. Mills \& H.C. BigGs. 2001. Factors affecting the hunting success of male and female lions in the Kruger National Park. Journal of Zoology, London 253: 419-431.

GRIFFITHS, D. 1975. Prey availability and the food of predators. Ecology 56: 1209-1214.
Harrington, R., N. Owen-Smith, P.C. Viljoen, H.C. Biggs, D.R. MASON \& P.C. Funston. 1999. Establishing the causes of the roan antelope decline in the Kruger National Park, South Africa. Biological conservation 90: 69-78.

HiRST, S.M.1969. Predation as a regulating factor of wild ungulate populations in a Transvaal lowveld Nature Reserve. Zoologica Africana 4(2): 199-230.

HunTER, L.T.B. 1998. The behavioural ecology of reintroduced lions and cheetahs in the Phinda Resource Reserve, Kwazulu-Natal, South Africa. $\mathrm{PhD}$ thesis, University of Pretoria, Pretoria.

Hunter, L.T.B \& J.D. SkInNER. 1997. Vigilance behaviour in African ungulates: the role of predation pressure. Behaviour 135: 195-211.

JAKOBY, M. 1997. The nutritional requirements of the predators in the Mabula Game Reserve and the sustainability of the lions in the Madjuma lion reserve. Honours project (Wildlife management), University of Pretoria. Pretoria.

Jefreries, M. J \& J.H. LaWton. 1984. Enemy-free space and the structure of ecological communities. Biological Journal of the Linnaen Society 23: 269-286.

KARANTH, K.U. \& M.E. SunQuist. 1995. Prey selection by tiger, leopard and dhole in tropical forests. Journal of Animal Ecology 64: 439-450.

KRUUK, H. 1986. Interactions between felidae and their prey species: a review. Pp. 353-374. In: Miller, S.D. \& D. Everett (eds.). Cats of the world: biology, conservation and management. Kingsville: Caesar Kleberg Wildlife Research Institute.

Madjuma Lion Reserve. 1997. Madjuma census figures. Mabula Game Reserve

MCBRIDE, C.J. 1984. Age and size categories of lions prey in the Chobe National Park, Botswana. Botswana Notes and Records 16: 139-143.

MiLls, M.G.L. 1984. Prey selection and feeding habits of the larger carnivores in the southern Kalahari. Koedoe (Supplement) 27: 281-294.

MiLLS, M.G.L. 1990. Kalahari hyaenas: comparative behavioural ecology of two species. London: Unwin.

MiLLS, M.G.L. 1991. Conservation management of large carnivores in Africa. Koedoe 34: 81-90.

MiLls, M.G.L. 1996. Methodological advances in capture, census, and food-habits studies of large African carnivores. Pp. 223-242. In: GittleMAN, J.L (ed.). Carnivore behaviour, ecology and evolution. London: Comstock.

Mills, M.G.L \& H.C. BigGs. 1993. Prey apportionment and related ecological relationships between large carnivores in the Kruger National Park. Symposia of the Zoological Society of London 65: 253-266. 
Mills, M.G.L. \& P.F. Retief. 1984. The response of ungulates to rainfall along the riverbeds of the southern Kalahari. Koedoe (Supplement) 27: 129-141.

Mills, M.G.L \& T.M. Shenk. 1992. Predator-prey relationships: the impact of lion predation on wildebeest and zebra populations. Journal of Animal Ecology 61: 693-702.

Mooring, M. 1999. Impala: the living fossil. Africa, Environment \& Wildlife 7(5): 53-61.

Neu, C.W., C.R. Byers \& J.M. PeeK. 1974. A technique for analysis of utilisation-availability data. Journal of Wildlife Management 38: 541-545.

Owen-Smith, N. 1984. Demography of the greater kudu, Tragelaphus strepsiceros in relation to rainfall. Acta Zoologica Fennica 172: 197-199.

Owen-SMith, N. 1993. Comparative mortality rates of male and female kudus: the costs of sexual size dimorphism. Journal of Animal Ecology 62: 428-440.

Packer, C., D. Scheel \& A. E. Pusey. 1990. Why lions form groups: food is not enough. American Naturalist 136: 1-19.

Peel, M.J.S. \& G.P. Montagu.1999. Modelling predator-prey interactions on a Northern Province game ranch. South African Journal of Wildlife Research 29(2): 31-34.

PienAar, U. DE V. P. 1969. Predator prey relationships amongst the large mammals of the Kruger National Park. Koedoe 12: 108-177.

POWER, R.J. 1998. The impact of lion Panthera leo predation and the sustainability of the Madjuma Lion Reserve, Mabula Game Reserve, Northern Province. BSc (Hons) (Wildlife management) project, University of Pretoria, Pretoria.

Schaller, G.B. 1972. The Serengeti lion: A study of predator-prey relations. Chicago: University of Chicago.

ScheEL, D. 1993. Profitability, encounter rates, and prey choice of African lions. Behavioural Ecology 4: 90-97.

SCHEEL, D. 1993. \& C. PACKER. 1991. Group hunting behaviour of lions: a search for cooperation. Animal Behaviour 41: 697-709.

SINCLAIR, A.R.E. 1995. Population consequences of predation-sensitive foraging: the Serengeti example. Ecology 76: 882-891.

Sinclair, A.R.E., H.T. Dublin \& M. BorNER. 1985. Population regulation of Serengeti wildebeest: a test of food hypothesis. Oecologia 65: 266-268.

SkinNER, J.D \& R.H.N. SMithers. 1990. The Mammals of the southern African subregion. Pretoria: University of Pretoria.

SMUTS, G.L. 1978. Interrelations between predators, prey and their environment. Bio Science 28: 316-320.
Sunquist, M. E. \& F.C. Sunquist. 1989. Ecological constraints on predation by large felids. Pp. 283-301. In: Gittleman, J.L (ed). Carnivore behaviour, ecology and evolution. London: Comstock.

STANDER, P.E. 1992a. Foraging dynamics of lions in a semi-arid environment. Canadian Journal of Zoology 70: 8-21.

STANDER, P.E. 1992b. Cooperative hunting in lions: the role of the individual. Behavioural Sociobiology 29: 445-454.

STANDER, P.E \& S.D. Albon. 1993. Hunting success of lions in a semi-arid environment. Symposium of the Zoological Society of London 65: 127-142.

VAN DYK, G. 1997. Reintroduction techniques for lion Panthera leo. Pp. 82-91. In: VAN HEERDEN. J. (ed.). Proceedings of a symposium on lions and leopards as game ranch animals. Pretoria: Wildlife group of the South African Veterinary Association, Onderstepoort.

VAn OrSDOL, K.G. 1982. Ranges and food habits of lions in Rwenzori National Park, Uganda. Symposia of the Zoological Society of London 49: 325-340.

VAN ORSDOL, K.G. 1984. Foraging behaviour and hunting success of lions in Queen Elizabeth National Park, Uganda. African Journal of Ecology 22: 79-99.

Van Rooyen, N. \& G. Bredenkamp. 1996. Mixed Bushveld. Pp 26. In: (eds.). Low, A.B \& A.G Rebelo (eds.). Vegetation of South Africa, Lesotho and Swaziland. Pretoria: Department of Environmental Affairs \& Tourism.

VAN SCHALKWYK, A.G. 1994. Riglyne vir die bestuur van leeus Panthera leo in ingeperkte gebiede in Suid-Afrika. MSc thesis (Wildlife management), University of Pretoria, Pretoria.

VILJOEN, P.C. 1993. The effects of changes in prey availability on lions predation in a natural ecosystem in northern Botswana. Symposium of the Zoological Society of London 65: 193-213.

Viluoen, P.C. 1996. Lions. Pp. 467-471. In: ВотHMA, J. DU P (ed.). Game ranch management. Pretoria: Van Schaik.

Whateley, A. \& P.M. Brooks.1985. The carnivores of the Hluhluwe and Umfolozi Game Reserves: 1973-1983. Lammergeyer 35: 1-27.

WeNTZEL, J.J., J DU P. BOTHMA \& N. VAN ROOYEN. 1991. Characteristics of the herbaceous layer in preferred grazing areas of six herbivore species in the south-eastern Kruger National Park. Koedoe 34(1): 57-58.

YounG, E. 1992. Game farming and wildlife management. Nylstroom: Eddie Young Publishers,

ZAR, J.H.1986. Biostatistical analysis. Englewood cliffs: Prentice-Hall. 